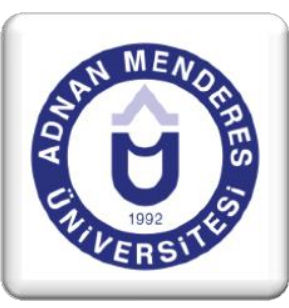

\title{
2000-2015 Yılları Arasında Düşünme Eğitimi Alanında Akademik Ĕgilimler
}

\author{
Kerim GÜNDOĞDU ${ }^{1}$, Özlem ERAYDIN ${ }^{2}$, Ayșegül \\ KIZILKAYA ${ }^{3}$
}

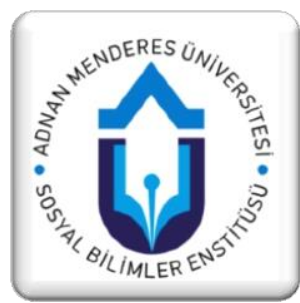

\section{ÖZET}

Bu çalışmanın amacı, ULAKBİM'de düşünme eğitimi ile ilgili 2000-2015 yılları arasında yayınlanan 25 makalenin içerik olarak yöntemleri, konu alanları, araştırmalarda kullanılan veri toplama araçları, veri analiz yöntemleri, kaynakçası ve örneklem özellikleri açılarından eğilimlerinin hangi yönde olduğunun içerik analizi yoluyla betimlenmesidir. Araştırma bulgularına ilișkin sayısal değerler yüzde ve frekans tabloları ve grafiklerle sunulmuştur. Araştırma bulgularına göre makale türü açısından araştırma incelemenin daha çok tercih edildiği görülmüştür. Çalışmalarda en çok nicel araştırma yöntemleri kullanılırken, veri toplama aracı olarak anket ve ilgi, tutum, algı, yetenek, kişilik ve başarı testlerinin sıklıkla kullanılan araçlar olduğu; veri analiz yöntemleri arasında da kestirimsel ve betimsel veri analizinin çok kullanıldığı belirlenmiştir. Örneklem grubu olarak lisans düzeyindeki öğrencilerin, öğretmenlerin ve ilköğretim 6-8. sınıf öğrencilerin olduğu, örneklem büyüklüğü olarak 31-100 ile 101-300 kişi arasında değişen grupların olduğu; örnekleme tekniği olarak da, basit seçkisizlik ve amaca uygunluk tekniğinin çok kullanıldı ̆̆ belirlenmiştir.

Anahtar Kelimeler: Düşünme, düşünme eğitimi, yansıtıcı, yaratıcı, eleştirel, meta bilişsel düşünme.

\section{Academic Tendencies on Thinking Education Between the Years of 2000-2015}

\begin{abstract}
The purpose of this study is to analyze the academic articles written on thinking education between the years of 2000 and 2015, in terms of their method parts mainly. The findings of the articles were subjected to content analysis done by the researchers, and all findings were presented in tables and figures. According to the results, field research type of articles were prefered to literatüre reviews by researchers in thinking education field. While quantitative approaches were applied, questionnaires perception, attitude, aptitude, personality and achivement scales/instruments were frequently used in these studies. Regarding data analysis, inferential and desriptive methods were conducted. Undergraduate and elementary school students and teachers were generally target groups in these studies. The participants whom collected data ranged between 31 to 300 by employing random or convenience sampling techniques.
\end{abstract}

Keywords: Thinking, thinking education, reflective, creative, critical, metacognitive thinking.

\footnotetext{
${ }^{1}$ Doç.Dr., Adnan Menderes Üniversitesi, Eğitim Fakültesi, Eğitim Programları ve Öğretim Ana Bilim Dalı.

${ }^{2}$ Zübeyde Hanım Mesleki ve Teknik Anadolu Lisesi, Aydın

${ }^{3}$ Adnan Menderes Üniversitesi, Aydın
} 


\section{Giriș}

1900'lü yılların başından itibaren öğrenme-öğretme sürecine bakış açısını etkileyen en önemli kavramlar, ilkeler ve olaylar psikoloji laboratuvarlarından elde edilenler ve davranışçı ekole atfedilenlerdir. Bu anlayış sonucunda, eğitim "bireyin davranışında kendi yaşantısı yoluyla ve kasıtlı olarak istendik değişme meydana getirme süreci" (Fidan, 2012, s.59) olarak tanımlanırken, günümüz anlayışında bireylerin sahip oldukları duyu organları aracılığıyla dış dünyadan-çevreden- elde ettiği uyarıcıları zihninde deneyimleyerek, gözlemleyerek ve etkin bir süreç deneyimi geliştirerek yeni bilişsel şemalar oluşturma süreci olarak görülmektedir (Perkins, 1999; Wilson, 1996).

Günümüz eğitim dünyasında yalnızca 'anlatarak' bilgiyi aktarmak yerine; öğrencinin doğru cevab1 kendisinin bulabilmesine yönelik 'düşünmeyi öğrenme' kavramı önem kazanmaktadır. Bu bağlamda düşünüldüğünde, günümüz dünyasında okul programlarının en önemli amac1 bilgiyi dikte eden değil, öğrencilerin üst düzey düşünme becerilerinin geliştirerek bilgiye ulaşmalarının sağlanmasıdır (Güneş, 2007). Bu yüzden modern okullarda tartışan, düşünen, eleştiren, üreten, problemlere çözüm yolları arayan, bilgiye ulaşma yollarını bilen bireyler yetiştirilmeye çalışılmaktadır. Fakat bu oldukça gayret ve zaman isteyen bir süreçtir. Bunun için de büyük bir titizlikle öğrencilerin düşünme süreçleri izlenmeli, özellikle soru sorma ve sorgulama konusu önemsenmeli, öğrencilere düşünme ve bilgiye ulaşma becerilerini kazandırmaya yönelik eğitim programları hazırlanmalıdır. Bunlara ilave olarak öğrencilerin bu bilişsel becerileri kazanmış olmaları, onların bu becerileri yaşamlarının her alanlarında etkili biçimde kullanacakları anlamına gelmemelidir. Öğrencilerin öğrendikleri bilişsel becerileri yaşamlarında etkili biçimde kullanabilmeleri için tüm eğitim programlarının buna göre düzenlenmesi ve tüm eğitmenlerin düşünme becerileri eğitimi almalarının sağlanması gerekmektedir. Unutulmamalıdır ki düşünebilen öğrenciler için, düşünebilen ve sorgulayabilen öğretmenlere ihtiyaç vardır. İstediğimiz öğrencilerde mükemmel düşünsel yetiler oluşturmaksa, onları sürekli ve sistemli olarak en etkili düşünme yöntemleriyle eğitmemiz gerekiyor. Ayrıca, bu büyük sorumlulukta en büyük pay öğretmenlere düşmektedir, (Kale, 1993).

İnsan düşünebilen bir varlık olma özelliğiyle diğer canlılardan ayrılır. Ancak düşünme kendi haline bırakıldığında, çoğu zaman önyargılı, çarpıtılmış, taraflı, bilgilendirilmemiş ve indirgemeci bir yapı gösterir. Yaşam tarzımız, eylemlerimiz tamamen düşünce kalitemize bağlıdır. Nasıl bir aileye doğduğumuz ve onların tutumlarını da küçümsememek gerekir. Böyle olmakla birlikte, düşüncede mükemmelliğe ulaşmak ancak ona düzenli olarak yatırım yapmakla mümkündür. Eğitim sistemi, okullar ve öğretmenlerin kaliteleri sorgulandıkça, bireylerin Millî Eğitimin amaçlarında belirtilen nitelikler ve beceriler doğrultusunda yetiştirilemedikleri ortak bir görüş̧ür. Okullarda yapılan eğitimin ezbere dayalı olması, öğrencilerin zihinsel yönden gelişmelerini engelleyecek, düşünme becerilerini geliştirecek yöntem ve etkinliklere fazla yer verilmemesi ve en önemlisi de başarının tek kriterinin not olması vb. gibi hususlardır.

Toplumların gelişmişlik düzeyini belirleyen en önemli etkenlerden biri, eğitim sisteminin ortaya koyduğu insan modeli olarak kabul görmektedir (Bilen, 2006). Bilim ve teknolojide yaşanan hızlı değişim, insanların bilgiye bakışını değiştirmiş ve bu da eğitim anlayışında bir değişimi ortaya çıkarmıştır. $\mathrm{Bu}$ değişimle birlikte, bilgili ve bu bilgiyi yerinde kullanan insanlar yetiştirebilmenin en önemli koşulu tabi ki eğitim olacaktır. Bu değişime paralel olarak, "bilimsel düşünme", "mantıklı düşünme", "1raksak düşünme", "yansıtıcı düşünme", "üretici düşünme", "eleştirel düşünme", yaratıcı düşünme" vb. konularda eğitim ve psikoloji alanında yapılan çalışmalar da önem kazanmıştır (Doğan, 2005). 
Düşünme becerileriyle ilgili tanımlamalara bakıldığında bir takım ortak noktaların varlığı dikkat çekmektedir. Bu ortak noktalar problem çözme ve karar vermede yoğunlaşmaktadır. Eleştirel düşünme, yaratıcı düşünme, problem çözme, sorgulayıcı düşünme gibi düşünme becerileri, hem ailede hem de okulda verilen eğitimler ve çeşitli süreçler dahilinde gelişmekte veya körelmektedir. Düşünme genel olarak, düşünmek durumu, duyum ve izlenimlerden, tasarımlardan ayrı olarak, aklın bağımsız ve kendine özgü durumu, karşılaştırmalar yapma, ayırma, birleştirme, bağlantıları ve biçimleri kavrama yetisi (TDK, 1998) olarak tanımlanabilir.

\subsection{Eleştirel düşünme}

Eleştirel düşünme, bireyin bir bilginin ya da iddianın doğruluğunu, gerçekliğini ve güvenirliğini kanıtlama, bir konu hakkında karar vermede çeşitli kriterlerden yararlanma, okuduğu ya da duyduğu bir şeye hemen inanmadan önce kanıt elde etmeye çalışma, başkalarının iddia ve düşüncelerini kabul etmeden önce, onlardan bunu deliller 1şığında ispatlamalarını isteme ve bunları yaparken açıklık, dürüstlük, tutarlılık, doğruluk gibi zihinsel ya da entelektüel becerilere sahip olma şeklinde tanımlayabiliriz. Eleştirel düşünme, düşünme eyleminde bulunurken sorgulamamız, riskleri görmemizi sağlayan düşünme becerisidir (Abrami, Borokhovski, Wade, Surkes, Tamim and Zhang, 2008; Özdemir, 2005)

\subsection{Yaratıcı düşünme}

Yaratıcılık kavramının İngilizce karşıllı̆ı "kreativitaet, creativity"dir. Latince "creare" kelimesinden gelir. Bu kelime, "doğurmak, yaratmak, meydana getirmek" anlamındadır. İnsanlar daha rahat, daha mutlu yaşamak için karşılaştıkları problemlere çözüm bulmak durumundadır. Problem çözme becerisi gelişmiş bireylerin yaratıcı düşünme gücü de üst düzeydedir.. Bu tür beceriler ise, meraklı, başarılı, coşkulu ve analitik bireylerde daha çok görülür. İnsanı yaratıcı ve yapıcı yetiştirmek günümüz eğitimin sistemlerinin de amacıdır. Öncelikle bireyin yaratıcıllğını geliştirmek için ona düşünmeyi öğretmek gerekir. Düşünmeyi öğrenmek için de kişinin farklı durumlarla karşı karşıya gelmesi gerekir. Bu farklı durumlar arasından seçim yapabilmek, karar verebilmek, algılayabilmek, yorumlayabilmek ve çözümleyebilmeyi gerektirir. Doğru düşünmeyi bilen birey var olan seçenekler arasından işe yarar olanları üretebilen, karar verebilen, sonuç çıkarabilen, ileriye dönük planlar yapabilen kişidir. Bilmek ve yapmak aynı şeyler olmadığından, yaratıcı olabilmek için deneyimlemek gerekir (İlhan Çakır, 2016). Literatür (Kim, 2005) alt IQ düzeye sahip bireylerin de yaratıcı olabileceklerini göstermektedir. Öğretmenin görevi öğrencilerin yaratıcılık potansiyellerini gözlemleyerek, süreç içerisinde yaratıc1lıklarını geliştirmeye dayalı öğrenme yaşantılarına daha sık yer vermektir.

\subsection{Yansıtıcı düşünme}

Eğitim ortamına etkin biçimde katılan bireyin öğrendiklerini kendi yaşantılarıyla harmanlaması, mantıklı ve bilgiye dayalı karar alması ve bunları yeni durumlarda kullanabilme becerisi yansitıcı düşünmedir (Duban ve Yanpar, 2010; Semerci, 2007). Birey geçmiş yaşantılarından ders çıkarır. Bilgilerini günlük yaşama transfer eder, özeleştiride bulunur. Yansitıcı düşünme kavramının oluşmasına ve gelişmesine John Dewey öncülük etmiş̧tir. Dewey, yansıtıcı düşünmenin ve öğrenmenin gerçekleşebilmesi için bireylerde bazı özelliklerin bulunması gerektiğine dikkat çekmiştir. Bunlar açık fikirlilik, samimilik ve sorumluluk gibi duyuşsal alan özellikleridir (Dolapçığlu, 2007). 


\subsection{Metabilișsel düșünme}

Bireyin bilişi ve öğrenmesiyle ilgili içsel faktörlerin işlevselliği, öğrenenin bu özelliklerinin farkında olmasıyla ilgilidir. Bu farkındalık, öğrenenin kendi öğrenmesiyle ilgili olarak sorumluluk alıp öğrenmesini yönlendirebilmesini sağlar. Öğrenenin kendi biliş ve öğrenme özellikleri hakkındaki farkındalığı ile ilgili olarak, ilgili literatürde çok sayıda kavramdan söz edilmektedir. Bunlardan birisi ve belki de en önemlisi "üst biliş" (metacognition) kavramıdır. En yalın tanımıyla, bireyin kendi düşünme süreçlerinin farkında olması ve bu süreçleri kontrol edebilmesidir (Akpınar ve Baltacı, 2011). Üst biliş, son yıllarda eğitimde dikkat çeken en önemli konular arasındadır. Bireyin öğrenmeyi hangi yollarla daha iyi gerçekleştirdiğini bilmesi, kendi düşünme süreçlerinin farkında olması ve bu süreçleri kontrol edebilmesi anlamına gelir. Bireyin kendi düşünmesinden, öğrenmesinden sorumlu olmas1, hedeflerini, kendine uygun stratejileri belirlemesi ve kendini değerlendirmesidir. Kısacası ne olduğunu, ne yapacağını, neye gücünün yeteceğini, nasıl yaparsa başarılı olacağını bilmesi ve buna uygun ortam oluşturmasıdır. Bu da çok önemli bir farkındalık gerektirir (Olğun, 2011)

\subsection{Iraksak düşünme}

Iraksak düşünme, yeni ve bilinenden farklı düşünceler ortaya koymayı içeren özgün bir süreçtir. Çocukların gelişen zihinlerinin yakınsak olarak eğitilmesine rağmen rraksak düşünme yetenekleri ihmal edilir. Yakınsak düşünceyle yaratıcılık gerçekleşemez. $\mathrm{Bu}$ düşünmede düşünceleri doğru yanıtların belirlenmesi doğrultusunda netleştirir ya da yakınlaştırır. Yakınsak düşünenler genelde ihtiyatlı ve duygusal açıdan tutukturlar. Iraksak düşünmeyi kullanan yaratıcı kişiler normalden farklı özelliklere sahiptir. Yaratıcı bireylerin özellikleri şu şekilde sıralanmaktadır: akıcı, esnek, ayrıntıcı, belirsizlikleri tolere edebilen, özgün, ilgi alanları geniş, hassas, meraklı, özgür, yansıtıc1, hareketli, odaklanma süreleri uzun olan, derin düşünen, hem kadın hem de erkeğe ilişkin özellikleri kişiliğinde barındıran ve espri anlayışı olan kişilerdir. Iraksak düşünme, yaşamın açı uçlu olmaya yönelen karmaşık sorularının çoğunu yanıtlamak için yararlıdır. Bir sorunun sayısız olası cevaplarını davet ederler. Bu sorular insanları çeşitli olasılıkları, seçenekleri ve sonuçları düşünmeye zorlarlar. Yaratıcılığın kaynağı ıraksak düşünmedir. Problem çözmede ıraksak düşünce kullanılır (Gartenhaus, 2000)

Görüldüğü üzere, literatürde birçok düşünme biçimi ve becerisi yer almaktadır. Tüm bunlara yer vermek burada olanaksızdır. Belirli dönemlerde eğitim alan yazınının genel bir değerlendirmesinin yapılması o döneme ilişkin ortaya konan araştırmaların niteliğine dair bilgi vermekle kalmaz, aynı zamanda daha sonraki araştırmalara da 1şık tutar (Erdem 2011). $\mathrm{Bu}$ araştırmada, ülkemizde özellikle 2005-2006 öğretim yılından itibaren uygulamaya konulan yapılandırmacı ögretim programları aracılığıyla, uzak amaçlarda hedef gösterilen, genel amaçlarda 1şık tutulan ve özel amaçlar aracıllğıyla da öğrencilerin kazanması beklenen düşünme becerilerinin ülkemizde 2000 yılından bu yana yazılan makalelerde ne tür bir yaklaşımla ele alındığı analiz edilmiştir.

\section{Yöntem}

$\mathrm{Bu}$ çalışmada amaca uygun olduğu düşünülen içerik analizi yöntemi kullanılmıştır. Çünkü içerik analizi birbirine benzeyen verileri belirli kavramlar ve temalar çerçevesinde bir araya getirmek ve bunları okuyucunun anlayabileceği bir biçimde düzenleyerek yorumlamaktır (Yıldırım ve Şimşek, 2016). İçerik analizi, belirli kurallara dayalı kodlamalarla bir metinin bazı sözcüklerinin daha küçük içerik kategorileri ile özetlendiği sistematik, yinelenebilir bir tekniktir (Büyüköztürk, Çakmak, Akgün, Karadeniz ve Demirel, 2011). İçerik analizi, basıll, 
görsel vb. materyallerin sistematik bir şekilde taranarak belli kategoriler bakımından tematik olarak analiz edilmesini kapsar.

Yapılan bu çalışmada "ULAKBİM Sosyal Bilimler Veri Tabanı" tarafından dizinlenen ve 2000-2015 yılları arasında yayınlanan tam metnine açık erişim bulunan makaleler, özellikle barındırdıkları yöntem bölümleri açısından analiz edilmiştir. Anahtar kelime olarak 'düşünme, düşünme eğitimi, yansıtıcı, yaratıcı, eleştirel, meta bilişsel düşünme' sözcükleri taramaya dahil edilmiştir. Sonrasında elde edilen makaleler araştırmacılar tarafından ilk incelemeye tabi tutulmuş ve bazı makaleler kriter listesine uymadığı ve özellikle yöntem bölümlerinin zayıflığ 1 nedeniyle elenmiştir. Bu kriterlere dayalı olarak elde edilen 25 akademik makale bu çalışmanın kapsamını oluşturmaktadır ve analiz sonuçları aşağıda verilmiştir.

\section{Bulgular}

\subsection{Yayımlandığı Dergi Türü}

Türkiye'de ULAKBİM veri tabanında dizinlenen düşünme eğitimi alanında yayınlanmış olan makaleler yayınlandığ1 dergilerin türüne göre incelendiğinde makalelerin \%84'ünün ulusal hakemli dergide, \%16'sının ise uluslararası hakemli dergide yayımlandığı belirlenmiştir. 25 makale içinden hakemsiz dergilerde yayınlanmış bir makale bulunmamaktadır. Makalelerin yayımlandığı dergi türüne göre dağılımı Tablo 1'de gösterilmiştir.

Tablo 1. Makalelerin Yayınlandığı Dergi Türü Göre Dağılımı

\begin{tabular}{|c|c|c|}
\hline Dergi Türü & $\mathbf{f}$ & $(\%)$ \\
\hline $\begin{array}{l}\text { Uluslararas1 } \quad \text { Hakemli } \\
\text { Dergi }\end{array}$ & 4 & 16.00 \\
\hline Ulusal Hakemli Dergi & 21 & 84.00 \\
\hline Toplam & 25 & 100.00 \\
\hline
\end{tabular}

\subsection{Yazar Sayısı}

Makaleler yazar sayısına göre incelendiğinde bunların \%68'i iki yazarlı, \%28'i bir yazarlı, $\%$ 4'ü ise üç yazarlıdır. Yazar sayısı 5'in üzerinde olan herhangi bir makaleye rastlanmamıştır. Makalelerin yazar sayısına göre dağılımı şekil Tablo 2'de gösterilmiştir.

Tablo 2. Makalelerin yazar sayısına göre dağılımı

\begin{tabular}{lll}
\hline Yazar Sayısı & $\mathbf{f}$ & $\mathbf{( \% )}$ \\
\hline 1 & 7 & 28.00 \\
2 & 17 & 68.00 \\
3 & 1 & 4.00 \\
\hline Toplam & $\mathbf{2 5}$ & $\mathbf{1 0 0 . 0 0}$ \\
\hline
\end{tabular}

\subsection{Yayımlanma Tarih Aralığı}

Makalelerin yıllara göre dağglımına bakıldı̆̆ında en çok çalışmanın 2008-2010 (\%40) tarihleri arasında ve 2004-2007 (\%28) yılları arasında yapıldığı belirlenmiştir. Makalelerin yıllara göre dağılımı şekil 1'de verilmiştir. 


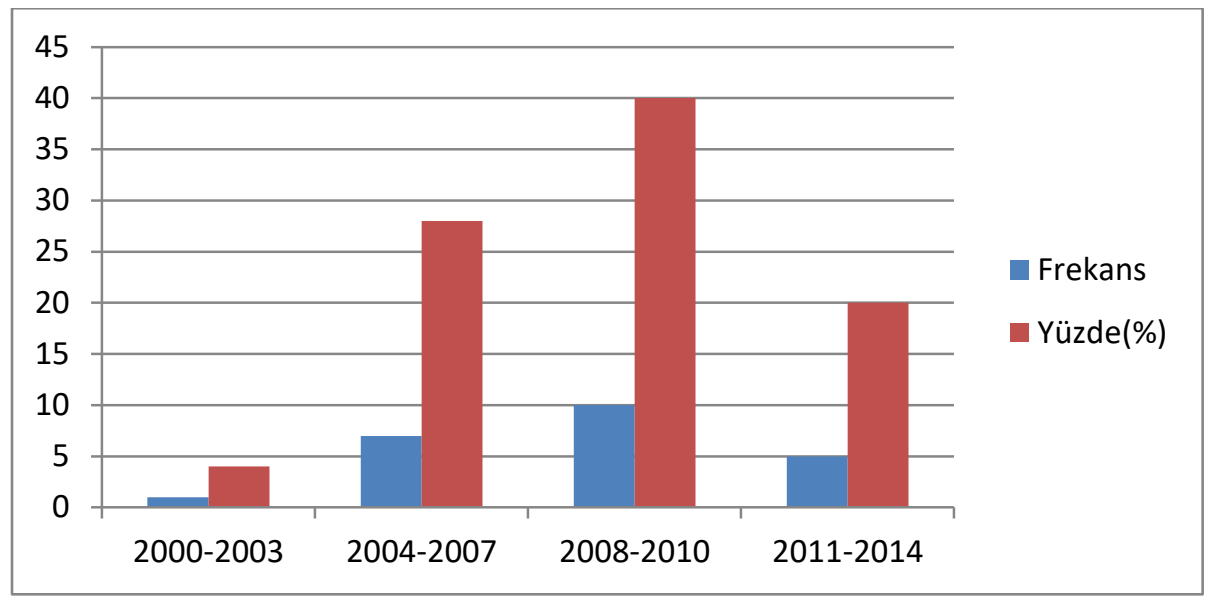

Şekil 1 Makalelerin yıllara göre dağılımı

\subsection{Araștırma Türleri}

Makalelerin yayımlandığı türlere göre incelendiğinde, düşünme eğitimi alanında yazılan akademik makalelerin büyük oranda araştırma temelli olarak yapıldığı görülmektedir (Şekil 2). Çok az sayıda araştırma kuramsal derleme çalışmaları niteliğindedir.

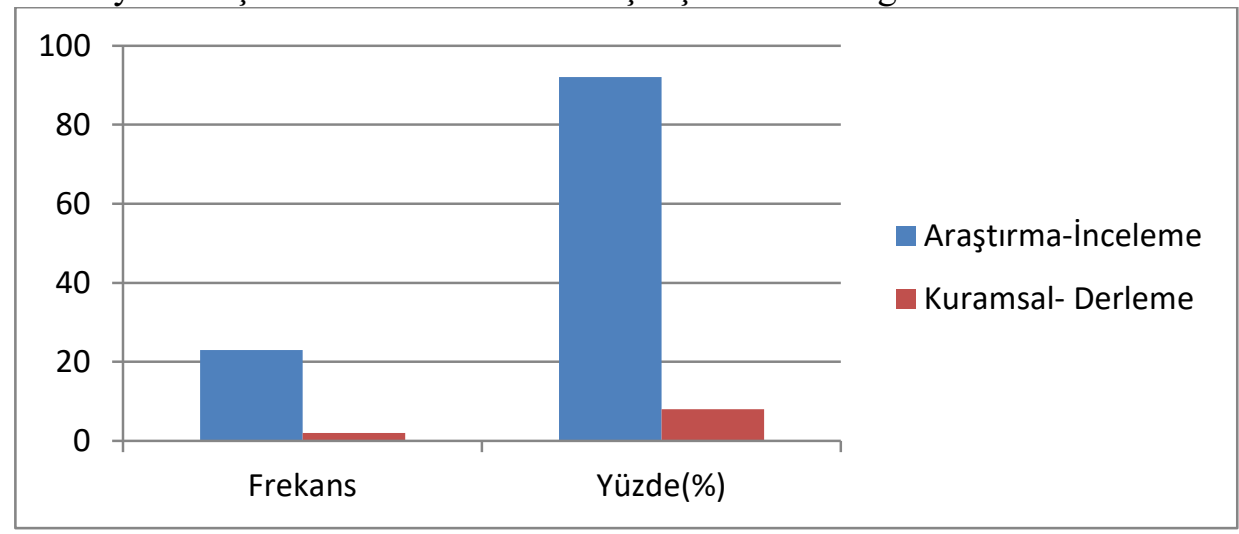

Şekil 2. Makalelerin araştırma türüne göre dağılımı

\subsection{Makalelerin Amacı}

Makaleler amaçlarına göre incelendiğinde, en çok çalışmanın düşünce algı tutum incelemesi (\%80) amacıyla yapıldığı belirlenmiştir. Program incelemesi ve değerlendirmesi amacı ile yapılan makale oranı \%12'dir. Literatür/doküman incelemesi, karşılaştırmalı betimleme ve uygulama amacı ile yapılmış bir makaleye rastlanılmamıştır. Makalelerin amaçlarına göre dağılımı Tablo 3'te verilmiştir. 
Tablo 3. Makalelerin Amaçlara Göre Dağılımı

\begin{tabular}{lll}
\hline Amaci & F & $\mathbf{( \% )}$ \\
\hline Düşünce/alg1/tutum incelemesi & 20 & 80.00 \\
Program İncelemesi/ Değerlendirmesi & 3 & 12.00 \\
Model önerisi & 1 & 4.00 \\
Diğer & 1 & 4.00 \\
\hline Toplam & $\mathbf{2 5}$ & $\mathbf{1 0 0 . 0 0}$ \\
\hline
\end{tabular}

\subsection{Seçilen Yöntemler}

ULAKBİM veri tabanında düşünme eğitimi ile ilgili makaleler yöntemlerine göre incelendiğinde nicel araştırma yöntemlerinin daha fazla tercih edildiği (\%48), bu nicel araştırmalar içerisinde betimsel tarama (\%28) ve gerçek deneysel (\%28) yöntemlerin daha fazla tercih edildiği görülmektedir. Karma (nicel ve nitel) \%12 oranında, nitel araştırmaların ise \%8'lik bir oranda yapıldığ 1 görülmüştür. İlginç bir şekilde, düşünme eğitimi gibi süreç temelli bir olgunun nitel araştırmada etkileşimli desene yönelik yöntemler aracılığıyla hiç çalışılmamış olması düşündürücüdür. Makalelerin yöntemlerine göre dağılımı Tablo 4'te gösterilmiştir.

Tablo 4. Makalelerin Araştırma Yöntemlerine Göre Dağılımı

\begin{tabular}{llll}
\hline Desen & Yöntem & f & $(\boldsymbol{\%})$ \\
\hline \multirow{3}{*}{ Deneysel Olmayan } & Yarı Deneysel & 7 & 28.00 \\
\cline { 2 - 4 } & Betimsel tarama & 7 & 28.00 \\
& İlişkisel tarama & 3 & 12.00 \\
Etkileşimli Olmayan & Karşılaştırmalı & 1 & 4.00 \\
\multirow{2}{*}{ Karma } & Ölçek geliş̧irme & 1 & 4.00 \\
\cline { 2 - 4 } & Kavram Analizi & 2 & 8.00 \\
\cline { 2 - 4 } & Açılayıcı (Nicel/Nitel) & 1 & 4.00 \\
\hline Toplam & Çeşitleme (Nicel+Nitel) & 2 & 8.00 \\
\hline
\end{tabular}

\subsection{Veri Toplama Araçları}

Makaleler veri toplama araçlarına göre incelendiğinde makalelerde birden fazla veri toplama aracının kullanıldığı belirlenmiş ve bu şekilde kodlama yapılmıştır. Veri toplama araçları ile ilgili veriler Tablo 5 'te verilmiştir. 
Tablo 5. Makalelerin veri toplama araçlarına göre dağılımı

\begin{tabular}{llcc}
\hline Desen & Yöntem & f & $(\mathbf{\%})$ \\
\hline \multirow{2}{*}{ Gözlem } & Käıüşme & 1 & 3.45 \\
\cline { 2 - 4 } & Yapılandırılmış & 1 & 3.45 \\
\cline { 2 - 4 } Başarı Testleri & Açık Uçlu & 1 & 3.45 \\
& Çoktan Seçmeli & 3 & 10.34 \\
& Diğer & 1 & 3.45 \\
\cline { 2 - 4 } Kişilik/Yetenek Testleri & Açık Uçlu & 1 & 3.45 \\
& Çoktan Seçmeli & 1 & 3.45 \\
& Diğer & 1 & 3.45 \\
\cline { 2 - 4 } & Açık Uçlu & 2 & 6.90 \\
Tutum/Alg1-Anket/Ölçek & Likert & 13 & 44.83 \\
& Diğer & 2 & 6.90 \\
\cline { 2 - 4 } Doküman & Dokümanlar & 1 & 3.45 \\
Alternatif & Ürün seçki dosyası vb. & 1 & 3.45 \\
\hline & & 29 & 100.00 \\
\hline
\end{tabular}

Yapılan araştırma sonucunda en çok tutum/alg1/anket/ölçek veri toplama aracı olarak kullanıldığı (\%58.62), bunları kişilik yetenek testleri (\%17.24) ve başarı testlerinin (\%17.24) takip ettiği gözlemlenmiştir. Gözlem, görüşme, doküman ve alternatif veri toplama araçlarının ise çok az sayıda kullanıldığı belirlenmiştir.

\section{8. Örneklem/Çalışma Grubu}

Çalışma grubu/örneklemlerin dağılımı Tablo 6'da gösterilmiştir. Tablo 6'ya göre, yapılan araştırmalarda örneklem veya çalışma grubu olarak en fazla lisans öğrencileri (\%51.85) seçilmiştir. Bu gurubu, öğretmenler (\%14.81) ve ilköğretim 6-8 öğrencileri (\%14.81) takip etmektedir. Ortaöğretim öğrencileri ise $\% 7.41$ oranında seçilmiştir.

Tablo 6 Makalelerin Örneklem Türüne Göre Dağılımı

\begin{tabular}{lcc}
\hline Örneklem/Çalışma Grubu & f & $\mathbf{( \% )}$ \\
\hline İlköğretim 1-5 & 1 & 3.70 \\
İlköğretim 6-8 & 4 & 14.81 \\
Ortaöğretim & 2 & 7.41 \\
Lisans & 14 & 51.85 \\
Lisansüstü & 1 & 3.70 \\
Öğretmenler & 4 & 14.81 \\
Diğgr & 1 & 3.70 \\
\hline Toplam & 27 & 100.00 \\
\hline
\end{tabular}




\section{9. Örneklem Büyüklüğü}

Örneklem büyüklüklerinin dağılımı Tablo 7'de gösterilmiştir. İncelenen makalelerde daha çok 31-100 (\%10) ile 101-100 (\%7) kişi arasında değişen örneklem büyüklükleri tercih edilmiştir. 1000'den fazla kullanılan örneklem sayısına rastlanmamıştır.

Tablo 7 Makalelerin örneklem büyüklüğüne göre dağılımı

\begin{tabular}{lll}
\hline Örneklem Büyüklü̆̆̈̈ & $\mathbf{f}$ & $(\boldsymbol{\%})$ \\
\hline $1-10$ aras1 & 1 & 4.35 \\
$11-30$ aras1 & 1 & 4.35 \\
$31-100$ aras1 & 10 & 43.48 \\
$101-300$ aras1 & 7 & 30.43 \\
$301-1000$ aras1 & 4 & 17.39 \\
\hline Toplam & 23 & 100.00 \\
\hline
\end{tabular}

\subsection{0. Örneklem Tekniği}

Makalelerde tercih edilen örneklem tekniklerine ilişkin veriler Tablo 8'de verilmiştir. Makalelerde örneklem tekniği olarak en çok rasgele/random (\%59.09) ve amaca uygun örnekleme (\%40.91) teknikleri kullanılmıştır. Kolay ulaşılabilir örnekleme ve evrenin tamamının tercih edildiği görülmemiştir.

Tablo 8 Makalelerin örneklem tekniğine göre dağılımı

\begin{tabular}{lll}
\hline Örneklem Tekniği & $\mathbf{f}$ & $\mathbf{( \% )}$ \\
\hline Rastgele/Random & 13 & 59.09 \\
Amaca Uygunluk & 9 & 40.91 \\
\hline Toplam & 22 & 100 \\
\hline
\end{tabular}

\subsection{Veri Toplama Yöntemleri}

Veri toplama araç türü dağılımı Tablo 9'da verilmektedir. Makaleler incelendiğinde verilerin en çok klasik (\%96) araç türü (kağıt kaleme dayalı) ile toplanıldı̆̆ı görülmektedir. Online ortamda veri toplamaya dayalı makaleye rastlanmamıştır.

Tablo 9. Makalelerin veri toplama yöntemlerine göre dağılımı

\begin{tabular}{lcc}
\hline Veri Toplama Araç Türü & f & $(\boldsymbol{\% )}$ \\
\hline Klasik & 24 & 96.00 \\
Karma & 1 & 4.00 \\
\hline Toplam & 25 & 100.00 \\
\hline
\end{tabular}

\subsection{Veri Analiz Yöntemleri}

Veri analiz yöntemlerinin dağılımın Tablo 10'da verilmiştir. İncelenen makalelerdeki veri analiz yöntemlerine bakıldığında en çok tercih edilen analiz yöntemi kestirimsel veri analizi tekniklerinden t-testi $(\% 38.10)$ ve ANOVA $(\% 26.11)$ en çok tercih edilen veri analiz yöntemleridir. Nitel veri analizi yöntemleri içerisinden en çok içerik analizi (\%4.76) yöntemleri tercih edilmiştir. 
Tablo 10 Makalelerin veri analiz yöntemlerine göre dağılımı

\begin{tabular}{llcc}
\hline Yöntem & Analiz & $\mathbf{f}$ & $\mathbf{( \% )}$ \\
\hline \multirow{3}{*}{ Nicel Analiz-Betimsel } & Frekans/Yüzde & 5 & 9.62 \\
& Ortalama/Standart Sapma & 7 & 13.46 \\
& Grafikle Gösterim & 2 & 3.85 \\
\cline { 2 - 4 } Korelasyon & 2 & 3.85 \\
& t-testi & 16 & 30.77 \\
& ANOVA & 11 & 21.15 \\
& Regresyon & 1 & 1.92 \\
& Diğer & 4 & 7.69 \\
\hline \multirow{3}{*}{ Nitel Analiz } & İçerik Analizi & 2 & 3.85 \\
& Betimsel analiz & 1 & 1.92 \\
\hline Toplam & Belirtilmemiş/Anlaşılmiyor & 1 & 1.92 \\
\hline
\end{tabular}

\subsection{Kaynak Sayıları}

Makaleler kaynak sayılarına göre incelendiğinde 25-30 arası kaynak sayısının \%24 oranında, 16-25 arası kaynak sayısının \%20 oranında ve 5-10 arası kaynak sayısının ise $\% 12$ oranında kullanıldığı sonucu çıkmaktadır. Makalelerin kaynak sayısına göre dağılııı Tablo 11'de verilmiştir.

Tablo 11 Makalelerin kaynak sayısına göre dağılımı

\begin{tabular}{lcc}
\hline Sayı & $\mathbf{f}$ & $\mathbf{( \% )}$ \\
\hline $5-15$ & 3 & 12.00 \\
$16-25$ & 5 & 20.00 \\
$26-35$ & 11 & 44.00 \\
36 üstü & 6 & 24.00 \\
\hline Toplam & 25 & 100.00 \\
\hline
\end{tabular}

\section{Sonuç ve Öneriler}

Düşünme eğitimi alanında yapılmış olan çalışmaları incelemeyi amaç edinen bu çalışma içerik analizi yöntemi kullanılarak yapılmıştır. Yapılan bu çalışma ULAKBİM veri tabanında dizinlenmiş dergilerde 2000-2015 yılları arasında yayınlanan toplam 25 adet makale ile sınırlandırılmıştır. İncelemeler yapılırken tezlerin yapıldığ 1 yıl, yöntemi, veri toplama araçları, örneklem özellikleri, veri analiz yöntemleri ve kullanılan kaynak sayısı hakkındaki bilgilere ulaşılmaya çalışılmıştır. Çalışma sonucunda elde edilen bulgular ele alınarak tartışılmış ve önerilerde bulunulmuştur.

Makalelerin yöntemleri desenlerine göre incelendiğinde nicel araştırmaların yoğunlukta olduğu görülmektedir. Nitel araştırmalar nicel araştırmalara göre daha derinlemesine bir çalışma gerektirdiğinden nicel araştırmalara göre daha az tercih edilmektedir., Hemphill, Richards, Templin ve Blankenship (2012) yapmış oldukları çalışmada nicel araştırmaların nitel ve karma (nitel ve nicel) araştırmalara göre daha fazla tercih edildiği bulgusuna ulaşmaları, Türkiye'de yapılmış içerik analiz çalışmaları bulgularını destekler niteliktedir. Çalışmalarda en çok betimsel ve yarı deneysel yöntemler kullanılmıştır. Araştırmacıların yarı 
deneysel yöntemi daha fazla kullanması Ozan ve Köse (2014)'ün yapmış oldukları içerik analiz çalışması bulguları ile örtüşmektedir.

İncelenen makalelerde en çok kullanılan veri analiz yöntemlerinin nicel analiz yöntemleri içerisinde t-testi ve ANOVA olduğu belirlenmiştir. Ayrıca veri analiz yöntemi sayısı olarak birden fazla yöntemin kullanıldığı görülmüştür. Erdem (2011) incelemiş olduğu makalelerde veri analiz yöntemi en fazla t-testi ve ANOVA yönteminin kullanıldığını tespit etmiştir. Dolayısı ile iki çalışmanın bulguları birbirlerini destekler niteliktedir. Bu bulgu nicel yöntemlerin daha fazla tercih edildiğine dair yukarıdaki bulgu ile de örtüşmektedir.

ULAKBİM veri tabanında düşünme eğitimi alanında 2000-2015 yılları arasında yapılmış olan makalelerin yıllara göre dağılımı incelendiğinde 2000-2003 yılları arasında yapılmış olan fazla sayıda makale olmadığı, 2004-2010 yılları arasında düşünme eğitimi alanında yapılmış olan çalışmalarda bir artı̧̧ olduğu ve 2011-2014 yılları arasında yapılmış olan çalışma sayısında bir düşüş olduğu tespit edilmiştir. Akaydın ve Çeçen (2011) yapmış oldukları içerik analizi çalışmasında 1990-2013 yılları arasında incelemiş oldukları makalelerin yıllara göre dağılımı çıkarmışlardır. Çalışmalarında yayınlanan makale sayısında 2006 yılından itibaren bir artış olduğu, 2012-2015 yılları arasında ise yayınlanan makale sayısında bir azalma görülmektedir. Dolayısıyla iki çalışmanın bulgularının birbiriyle paralel olduğu görülmektedir. Neden böyle olmuş alabilir, bu yıllarda konuya olan ilgi azalmış mı? Yoksa bir doygunluğa $\mathrm{m} ı$ ulaştı?

Makaleler araştırma türlerine göre incelendiğinde çalışmaların büyük bir çoğunluğunun araştırma-inceleme amacı ile yapıldığ 1 tespit edilmiştir. Walia ve Kaur (2012) İngiltere ve Amerika'da yayınlanmış olan makalelerin eğilimlerini belirlemek amacı ile bir içerik analiz çalışması yapmışlar ve makalelerin en çok araştırma-inceleme amacı ile yapıldığını tespit etmiş̧lerdir. Sonuç olarak, bu çalışmanın giriş kısmında verilmiş olan Türkiye'de yapılmış içerik analizi çalışmalarına ait bulgular bu çalışmada elde edilen verileridestekler niteliktedir.

İncelenen çalışmalar örneklem türü açısından ele alındığında eğilimin daha çok lisans öğrencileri üzerinde yoğunlaştığı ve örneklem büyüklüğünün 31-100 arasında olduğu görülmektedir. Öte yandan makalelerde en çok /rastgele örneklem tekniğinin kullanıldığ belirlenmiştir. Lu, Wu ve Chiu (2009) yapmış oldukları çalışmada Social Sciences Citation Index (SSCI)'de yayınlanmış olan makaleleri incelemişler ve örneklem türü olarak en çok lisans öğrencilerinin seçildiğini tespit etmişlerdir. Yapmış oldukları bu çalışma seçilen örneklem türü açısından Türkiye'de yapılmış olan araştırma bulguları ile benzerlik göstermektedir.

Makalelerde veri toplama yöntemi olarak en fazla klasik yöntemin kullanıldığ görülmektedir. Selçuk, Palancı, Kandemir ve Dündar., (2014)'ın yapmış oldukları çalışma bulguları da bu bulguyla benzer sonuçlara sahiptir. Ayrıca incelenen makalelerde anketin en çok kullanılan veri toplama aracı olduğu tespit edilmiştir. Erdem (2011) yapmış olduğu bir içerik analizi çalışmasında anketlerin en çok kullanılan veri toplama aracı olduğunu tespit etmiş olması düşünme eğitimi alanında yapılmış olan bu çalışmanın bulgularını desteklemektedir.

$\mathrm{Bu}$ araştırmanın sonuçlarının düşünme eğitimi ile ilgili eğitim araştırmalarına yön vermesi açısından bir yol gösterici olacağına inanılmaktadır. Elde edilen bulgular neticesinde şu önerilerin dikkate alınması yarar sağlayabilir;

1. Araştırmalarda nicel araştırmaların yanında karma (nicel ve nitel) araştırmalara ağırlık verilmesi çalışmalarda daha güvenilir sonuçlar elde edilmesini sağlayabilir. 
2. Uluslararası eğitim dergilerinde düşünme eğitimi ile ilgili yapılmış makaleler ile ulusal dergilerde yayınlanmış dergiler incelenip karşılaştırma yapılabilir. Böylece Türkiye'de düşünme eğitimi alanındaki eksiklikler belirlenebilir.

3. Araştırmaların örneklemlerine ağırlıklı olarak lisans öğrencilerinin seçilmiş olduğu tespit edilmiştir. Ookul öncesi, ilköğretim ve ortaöğretim) öğrencilerinden oluşan çalışma grupları ile de araştırmalar yürütülebilirYapılan araştırmada veri toplama amacı ile genellikle tek tip araç kullanıldığı tespit edilmiştir. Daha geçerli veriler elde etmek amacı ile birden fazla veri toplama aracı kullanılabilir. Veri çeşitlemesine gidilerek daha güvenilir sonuçlara ulaşılabilir.

4. Yapılacak olan çalışmaların örneklem sayısının artırılarak, araștırma sonucunun evrene genellemesi sağlanabilir. 


\section{KAYNAKÇA}

ABRAMİ, P. C. et al. (2008). Instructional interventions affecting critical thinking skills and dispositions: A stage 1 meta-analysis. Review Of Educational Research, 78 (4), 11021134.

AKAYDIN, Ş. ve ÇEÇEN, M. (2015). Okuma becerileri ile ilgili makaleler üzerine bir içerik analizi. Eğitim ve Bilim, 40(178), s.183-198.

AKPINAR B. ve, BALTACI, M. (2011). Web tabanlı öğretimin öğrenenlerin üst biliş farkındalık düzeyine etkisi. Mustafa Kemal Üniversitesi Sosyal Bilimler Enstitüsü Dergisi, 8(16), 319-333.

BİLEN, MÜNEVVER, (2006). Plandan uygulamaya öğretim (7.Bask1). Ankara: An1 Yayınc1lı.

BÜYÜKÖZTÜRK, Ş., KILIÇ-ÇAKMAK E., AKGÜN, Ö. E., KARADENIZ, Ş. ve DEMIREL, F. (2011). Bilimsel araştırma yöntemleri (10. bask1).Ankara: Pegem A Yayıncilik.

DOLAPÇIOĞLU, S. D. (2007). Sinıf öğretmenlerinin yansitıcı düşünme düzeylerinin değerlendirilmesi, Yüksek Lisans Tezi, Mustafa Kemal Üniversitesi Sosyal Bilimler Enstitüsü, Hatay.

DOĞAN, N. (2005). Yaratıcı Düşünme. Demirel Ö. (Ed.), Eğitimde Yeni Yönelimler (2. Bask1). Ankara: Pegem A Yayınc1lık.

DUBAN, N. ve YANPAR, T. (2010). Öğretmen adaylarının yansıtıcı düşünme eğilimleri ve yansıtıcı öğretmen özellikleriyle ilgili görüşleri. Ç.Ü. Sosyal Bilimler Enstitüsü Dergisi, 19(2), 343-360.

ERDEM, D. (2011). Türkiye'de 2005-2006 y1lları arasında yayımlanan egitim bilimleri dergilerindeki makalelerin bazı ozellikler acisından incelenmesi: Betimsel bir analiz. Egitimde ve Psikolojide Olcme ve Degerlendirme Dergisi, 2(1), 140-147.

FIDAN, N. (2012). Eğitimde yeni kavramlar ve ilkeler (3.bask1). Ankara: PegemA.

GARTENHAUS, A. R. (2000). Yaratıcı Düşünme ve Müzeler (Çev. R. Mergenci ve B. Onur. Ankara Üniversitesi Çocuk Kültürü Araştırma ve Uygulama Merkezi Yayınları No:7.

GÜNEŞ, F. (2010). Eğitimde yapılandırıcı yaklaşımla gelen yenilikler. Eğitime Bakış, 6(16), 3-9

HEMPHILL, M. A., RİCHARDS, K.A.R., TEMPLIN, T.J. and BLANKENSHIP, B.T. (2012). A content analysis of qualitative research in the journal of teaching in physical education from 1998 to 2008. Journal Of Teaching In Physical Education, 31 (2), 279-287.

İLHAN ÇAKIR, A. (2016). Yaratıcı düşünmenin geliştirilmesi. 80.251.40.59/education.ankara.edu.tr/ilhan/makaleler/M40.doc adresinden 01.11.2016 tarihinde alınmıştır.

KALE, N. (1993). Eğitime ilişkin felsefi ve ideolojik görüşler realizm ve eğitim. http://dergiler.ankara.edu.tr/dergiler/40/498/5959.pdf adresinden 01.11.2016 tarihinde alınmıştır.

KİM, K. (2005). Can only intelligent people be creative? A meta analysis. The Journal of 
Secondary Gifted Education, 2(3), s.57-66.

LU, H.M., WU, C.Y. and CHIU, C.H. (2009). Research Trends in E-learning from 2005 to 2007: a Content Analysis of the Articles Published in Selected Journals. In G. Siemens \& C. Fulford (Eds.), Proceedings of EdMedia: World Conference on Educational Media and Technology 2009 (pp. 2619-2628). Association for the Advancement of Computing in Education (AACE).

OLĞUN, M. (2011). İlkögrretim 4. sinif fen ve teknoloji dersinde öz ve akran değerlendirme uygulamalarının yer aldı ̆̆ işbirlikli ögrenme yönteminin öğrencilerin başarı, tutum ve biliş üstü becerilerine etkisi. Yayımlanmamış Doktora Tezi. Dokuz Eylül Üniversitesi Eğitim Bilimleri Enstitüsü, İzmir.

OZAN, C. ve KÖSE E. (2014). Eğitim programları ve öğretim alanındaki araştırma eğilimleri. Sakarya Üniversitesi Eğitim Fakültesi Dergisi, 4(1), 116-136.

ÖZDEMİR, S.M. (2005). Üniversite öğrencilerinin eleştirel düşünme becerilerinin çeşitli değişkenler açısından değerlendirilmesi. Türk Eğitim Bilimleri Dergisi, 3(3), ss.297314.

PERKINSS, D. (1999). The many faces of constructivism. Educational Leadership, 57, 6-11

SEFEROĞLU, S. S. ve Akbıyık Cenk (2006). Eleştirel düşünme ve öğretimi. Hacettepe Üniversitesi Ë̌itim Fakültesi Dergisi, 30, 193-200.

SELÇUK, Z., PALANCI, M., KANDEMIR, M. ve DÜNDAR, H. (2014). Eğitim ve Bilim dergisinde yayınlanan araştırmaların eğilimleri: İçerik analizi. Eğitim ve Bilim, 39(173), 430-453.

SEMERCI, Ç. (2007). Öğretmen ve öğretmen adayları için yansıtıcı düşünme eğilimi (YANDE) ölçeğinin geliştirilmesi, Kuram ve Uygulamada Eğitim Bilimleri, 7 (3), 1351-1377.

SEVERIENS, S. and TENDAM, G. (1994). Gender Differences In Learning Styles: A narrative review and quantitative meta-analysis. Higher Education, 1 (27), 487-501.

TDK (1998). Türk Dil Kurumu Türkçe Sözlüğü. TDK Yayınları: Ankara.

WILSON, B. G. (1997). Reflections on constructivism and lnstructional design, Denver, Englewood Cliiffs NJ. Educational Technology Publications.

YILDIRIM, A. ve ŞIMŞEK, H. (2016). Sosyal Bilimlerde Nitel Araştırma Yöntemleri (10. Baskı). Ankara: Seçkin Yayıncılık. 